\title{
Spatial distribution of microregions specialized in milk production
}

\section{Distribuição espacial de microrregiões especializadas na produção de leite}

\author{
Tiago Santos Telles ${ }^{1 *}$; Matheus Demambre Bacchi²; Jaime Shimizu ${ }^{3}$
}

\begin{abstract}
The aim of this study was to verify and characterizes the spatial distribution of the microregions specialized in bovine milk production in Paraná State, Brazil, using data from the Municipal Livestock Survey conducted by the Brazilian Institute of Geography and Statistics and the Central Bank of Brazil's National Program to Strengthen Household Agriculture (PRONAF), from 2000 to 2012. Methodologically, we carry out location quotient (LQ), principal component, (PCA) and cluster analyses. Based on the results of the LQ, of the 39 microregions in Paraná State analyzed, 13 are identified as specializing in milk production. In particular, the West and Southwest mesoregions as well as the microregion of Ponta Grossa, in relative terms, account for $58 \%$ of the milk produced in the study period. Additionally, based on the PCA, 2 principal components are found to explain $91.5 \%$ of the variability in the data, termed technically enhanced production and household production. Finally, by using cluster analysis, five groups are identified among the microregions specializing in milk production, thus indicating marked heterogeneity across the state. This situation requires the expansion of public policies that mitigate regional disparities and provide the state with production gains from milk farming. Key words: Animal production. Bovine milk production. Regional development. Paraná State. Brazil
\end{abstract}

\section{Resumo}

O objetivo deste estudo foi verificar e caracterizar a distribuição espacial das microrregiões paranaenses especializadas na produção de leite bovino. Para tanto foram utilizados dados da Pesquisa Pecuária Municipal do Instituto Brasileiro de Geografia e Estatística e do Programa Nacional de Fortalecimento da Agricultura Familiar, do Banco Central do Brasil, referentes aos anos de 2000 a 2012. Foram realizadas análises do quociente locacional (QL), de componentes principais (ACP) e de agrupamentos. A partir dos resultados do QL foram identificadas 13 microrregiões paranaenses especializadas na produção de leite dentre as 39 existentes. Além disso, constatou-se que as mesorregiões oeste e sudoeste e a microrregião de Ponta Grossa, em termos relativos, responderam por $58 \%$ do valor bruto da produção do leite no período analisado. Ademais, a partir da ACP, foram identificados 2 componentes principais, suficientes para explicar $91,5 \%$ da variabilidade dos dados, sendo nominados de produção tecnificada e produção familiar. Entre as microrregiões especializadas na produção de leite, por meio da análise de agrupamentos, foram identificados 5 grupos, indicando uma acentuada heterogeneidade no estado. A conjuntura que se apresenta requer a formulação de políticas públicas que amenizem as disparidades regionais e que possam proporcionar ao estado ganhos de produção na atividade leiteira.

Palavras-chave: Produção animal. Bovinocultura de leite. Desenvolvimento regional. Paraná. Brasil.

\footnotetext{
${ }^{1}$ Pesquisador, Área de Socioeconomia, Instituto Agronômico do Paraná, IAPAR, Londrina, PR, Brasil. E-mail: telles@iapar.br

2 Economista, Universidade Estadual de Londrina, UEL, Londrina, PR, Brasil. E-mail: matheus.dbacchi@gmail.com

3 Discente de Graduação, UEL, Londrina, PR, Brasil. E-mail: jaimeshimizu@gmail.com

* Author for correspondence
} 


\section{Introduction}

In 2014, bovine milk production in Paraná State reached nearly 4.5 billion liters, representing $13 \%$ of total production in Brazil (IBGE, 2015). Production is distributed throughout Paraná, leading to significantly different production processes among its microregions (BAZOTTI et al., 2012; CAPUCHO; PARRÉ, 2012). This herogeneity coupled with the technical and organizational growth of this sector has required producers to adapt their facilities (BORTOLETO; CHABARIBERY, 1998; CHADDAD， 2007). In particular, given the complexity of the field of agriculture, especially because of its diverse landscape and existence of different types of farmers, this has resulted in tailored survival and production strategies, leading them to respond differently to similar challenges and limitations (TELLES et al., 2008). These disparities tend to highlight the differences, especially technological , among the microregions specializing in milk production in Paraná State. In summary, both the different edaphoclimatic conditions among microregions and the diverse interests of the involved agents contribute to the heterogeneity of its milk production.In other words, the differences do not only apply to geo-physical characteristics, but also to production indicators, expressed by the existing production and faming structure in the state's microregions. Thus, it is worth to take into account that there are farmers specialized in activity and establishments. For them, milk production is a secondary activity, pursued for subsistence or to receive an additional income (LEMOS et al., 2003; TELLES et al., 2008).

Despite this degree of complexity, there is a lack of information available about the milk industry, especially regarding the specialization of milkproducing microregions. Data on the production rates and technological standards adopted by farmers are typically unavailable. Thus, research studies that aim to characterize and map milk production constitute an important tool for guiding public and private agents. Such research can help steer assistance and support programs for farmers as well as develop new strategies for raising production (MONTEIRO et al., 2007; SANTOS; AZEVEDO, 2009).

Brazilian studies that examine milk production have combined multivariate statistical tools with spatial analysis, using techniques such as location quotient (LQ) analysis, principal component analysis (PCA), and cluster analysis. However, these studies were conducted only for the states of Minas Gerais (LEMOS et al., 2003) and Rio Grande do Sul (MARION FILHO; OLIVEIRA, 2011; MARION FILHO et al., 2012, 2015) as well as for southern Brazil (FERNANDES et al., 2004) and Western Paraná (LANGE et al., 2016). In this context, the need for data that provide a more detailed characterization of the spatial distribution of the microregions specialized in milk production in Paraná State is clear.

Due to the dynamics and complexity of planning in the livestock sector, the characterization and mapping of milk activity are important tools. In other words, there is a need for control and constant update of information related to this activity. Given the variety and diversity of milk livestock in spatial terms and of the existing production system, constantly updated information on milk production activities is crucial, especially to allow both the planning and the implementation of public actions focused on these activities. Indeed, as spatial transformations occur over time, the regions specialized in milk production must become the focus of public and private actions to ensure the technological and economic development of a certain region or livestock activity.

Against this background, this study verifies and characterizes the spatial distribution of the microregions in Paraná State specialized in bovine milk production. 


\section{Materials and Methods}

This study used data from the Municipal Livestock Production conducted by the Brazilian Institute of Geography and Statistics (IBGE, 2015) and the National Program to Strengthen Family Farming (PRONAF) available by the Central Bank of Brazil (BCB, 2015), from 2000 to 2012. The analyses covered the 39 microregions in Paraná State, as defined by the $\mathrm{IBGE}^{4}$. The following variables were considered for each microregion: average milk production (i.e., the amount of milk produced divided by the number of milked cows - productivity), average gross production value (GPV), PRONAF's average resources (i.e., the sum of the resources aimed at costs and investments in each microregion) and the LQ. The LQ is a relative measure of regional specialization that compares certain activities based on a basic aggregate (MARION FILHO et al., 2015). In this study, this parameter was used to determine the specialization of milk production in the microregions of Paraná State based on the average GPV throughout the study period. The LQ value was obtained based on the milk GPV and livestock GPV ratio, according to Equation 1 (ISARD, 1960):

$$
Q L=\frac{\frac{E_{j}^{i}}{E_{j}}}{\frac{E^{i}}{E}}
$$

where $E_{j}^{i}$ is activity $i$ in region $j ; E_{j}$ is the total activity in region $j ; E^{i}$ is activity $i$ all regions; and $E$ is all activities in all regions.

In Equation (1), the numerator represents the division between milk producers in a certain

\footnotetext{
${ }^{4}$ Assaí, Astorga, Campo Mourão, Capanema, Cascavel, Cerro Azul, Cianorte, Cornélio Procópio, Curitiba, Faxinal, Floraí, Ibaiti, Foz do Iguaçu, Francisco Beltrão, Goioerê, Guarapuava, Ivaiporã, Irati, Jacarezinho, Lapa, Londrina Maringá, Palmas, Paranaguá, Paranavaí, Pitanga, Pato Branco, Ponta Grossa, Porecatu, Prudentópolis, Rio Negro, São Mateus do Sul, Telêmaco Borba, Toledo, União da Vitória, Umuarama, and Wenceslau Braz.
}

microregion based on total livestock production in the microregion, while the denominator represents the division between milk producers in Paraná State based on total livestock production in the state. When the result obtained is greater than (less than) 1 , there is (no) milk specialization in the microregion analyzed.

After the microregions in Paraná State were defined as being specialized or unspecialized in milk production, a PCA was performed. According to Fávero et al. (2009), PCA considers the total variance of the data and seeks a linear combination of the observed variables to maximize the total variance explained. If the variables are highly correlated, they are then combined, creating a factor, or component, that explains the greater amount of variance in the sample. The second component will have the second greatest variance and will not be correlated with the first one, and so on.

Based on the PCA results, a cluster analysis of the microregions was then performed, using as the parameter their degree of similarity. This is an interdependent statistical technique that enables clustering variables into homogeneous groups based on certain parameters, according to a measure of similarity or distance (FÁVERO; BELFIORE, 2015).

The methodological procedures for the LQ, PC, and cluster analyses followed those used by Lemos et al. (2003). The monetary amounts were updated into Brazilian real (R\$) at December 2014 rates, based on the Broad National Consumer Price Index (IPCA), provided by the IBGE. SPSS v. 21 software was used to calculate the data and ArcGIS 10.2 software was used to create the maps.

\section{Results and Discussion}

Table 1 shows the number of milked cows, amount of milk produced, and average productivity by mesoregion in Paraná State. 
The data show that except for the North Central mesoregion, which decreased by $19.4 \%$, the number of milked cows increased at a rate of $49.2 \%$ across the state throughout the study period. The Mid-South mesoregion showed the greatest growth rate $(256.4 \%)$ followed by the North Pioneer mesoregion at $118.2 \%$ and the Mid-East mesoregion at $55.8 \%$. The Southwest mesoregion had the highest number of milked cows $(9.2 \%$ of the herd in Paraná), which represents an increase in production of $57.2 \%$ between 2000 and 2014, well above the state average.

In 2014, the west mesoregion was the largest milk producer in Paraná State, accounting for $24 \%$ of total milk production, with a growth rate of $181 \%$ between 2000 and 2014. As with the number of milked cows above, milk production in the North Central mesoregion declined at a rate of $10.7 \%$ during the study period, whereas it rose in all other mesoregions. In terms of average productivity, a decrease of $12 \%$ throughout the study period was noted in the Metropolitan Curitiba region compared with a growth rate of $68 \%$ at the state level. The most productive mesoregions were Mid-East at 4.77 thousand liters of milk per cow per year, west at 3.59 thousand, and Southwest at 3.25 thousand. The Southwest mesoregion presented the greatest growth rate in average production (141\%) followed by the west and Mid-East mesoregions at $80.9 \%$ and $79.8 \%$, respectively.
Table 1 also shows that milk production in Paraná State is concentrated in three regions, namely Mid-East, West, and Southwest, which together accounted for $61 \%$ of statewide production. This heterogeneity among milk farmers in Paraná State is due to the technology adopted by different production units, among other factors. Moreover, the coexistence of large-scale milk producers that use high-level technology and small producers characterized by small herds without genetic improvement underlies the disparities in milk production activities (ZOCCAL; GOMES, 2005). However, although major producers account for the greatest share of production, small producers are indispensable for milk production at the state level (BAZOTTI et al., 2012). Indeed, based on the 2006 Livestock Census (IBGE, 2007), household agriculture represents $84.2 \%$ of bovine milk producers in the state. The greatest number of these establishments lies in the west mesoregion (16.7\%), followed by Mid-South (14.6\%) and North Central (12.7\%). According to Martins (2004), this diversity is strongly related to the structure of milk production, which has changed considerably since the 1990s. This changing structure has increased the need for knowledge on and the characterization of this activity, especially regarding the regional nuances of production systems. Many of these changes, which started with the public deregulation of the market, have also led to a significant expansion of capital in rural areas. 


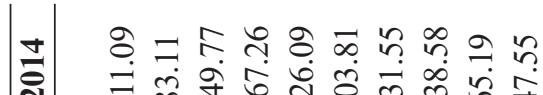

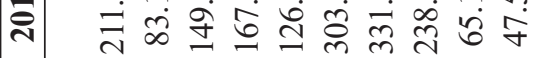

m กิ กิ

बี

ก

ปี

$=\quad \infty \infty \infty \%$

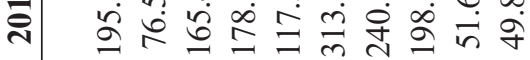

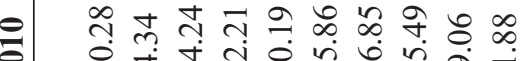

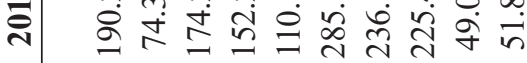

อิ

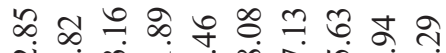

শ

\&

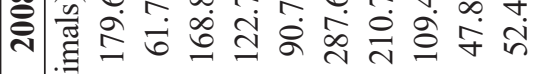

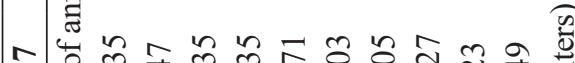

ิㅡㅇ

(1)

¿ัڤ

(⿸丆口

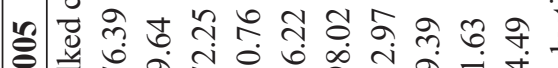

글

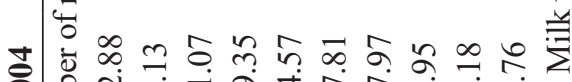

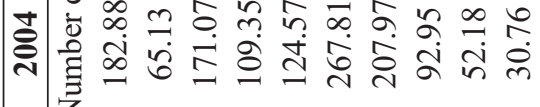

\% m

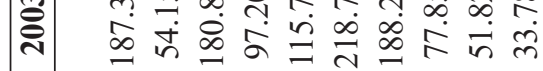

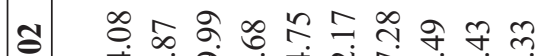

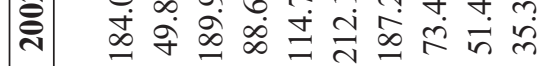

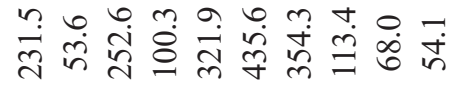

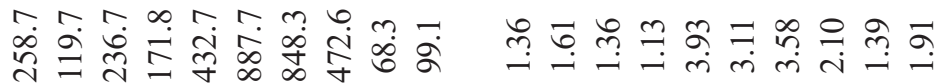

की

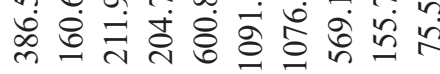

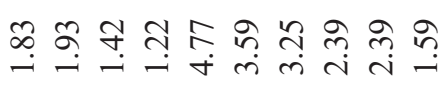

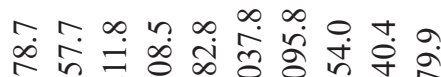

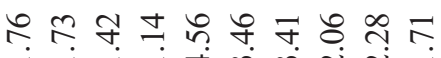

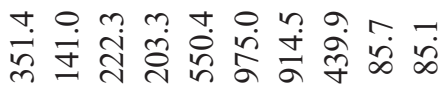

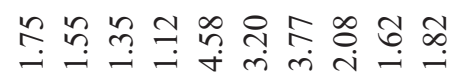

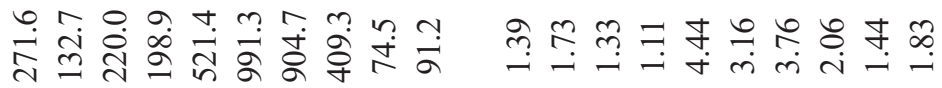

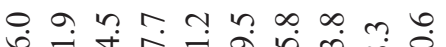

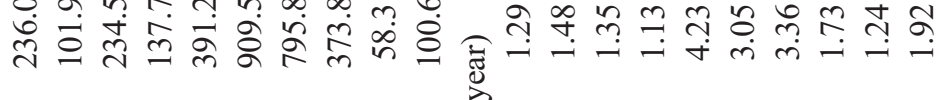

กm

तิ

.

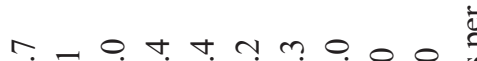

- क

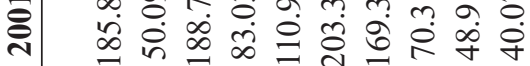

กั

ปิ่

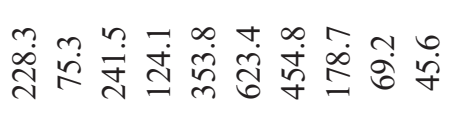

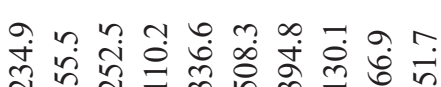

它 离

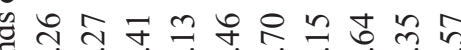

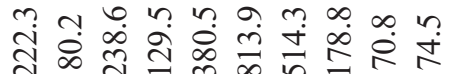

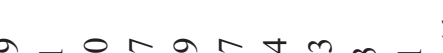

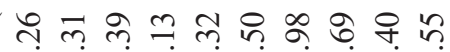

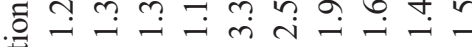

aำ घ

要

ำㅇำ

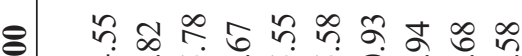

อ. n mor

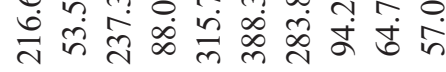

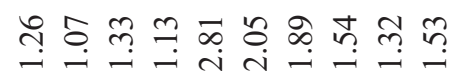

กุ

$-\dot{-}-\dot{i}-\dot{i}-\dot{-}$

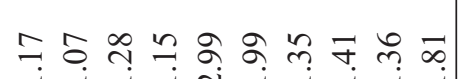

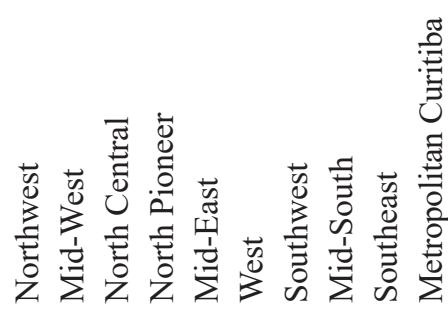

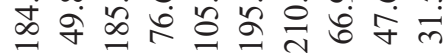

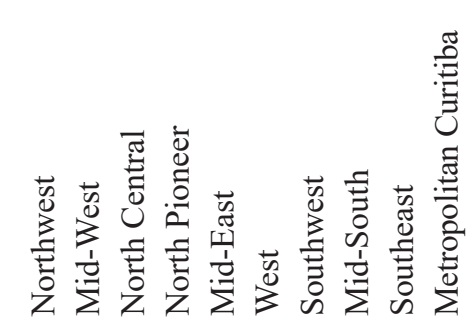

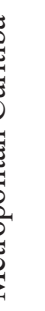

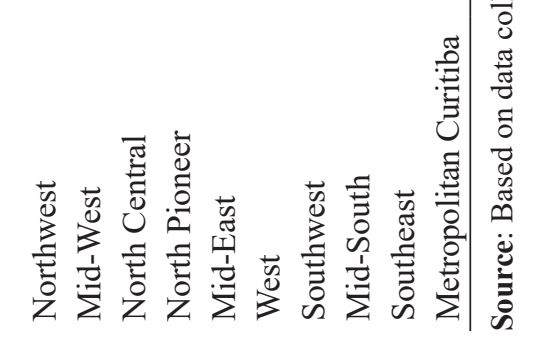


One of the likely causes of these regional inequalities in milk production in Paraná State is that the most productive milk systems work in close relation with cattle farming, making use of production, advanced genetics, and nutritional control methods. By contrast, lower-level production systems are typically not technically enhanced. Other variables that can differentiate milk-producing regions include the use of manual labor, herds with predominantly milk-producing breeds, suitable nutritional management, and a cooperative production structure. However, since these factors show regional variations, a study of the differences between the most and least specialized microregions is important (CAPUCHO; PARRÉ, 2012).

The results of the LQ analysis highlight 13 microregions specializing in milk production in Paraná State (see Figure 1), namely (in decreasing order of specialization) Ponta Grossa, Francisco Beltrão, Capanema, Pato Branco, Jaguariaíva, Foz do Iguaçu, Toledo, Pitanga, Paranavaí, Wenceslau Braz, Cascavel, Palmas, and Umuarama. These 13 microregions account for approximately $75 \%$ of milk GPV in the state. Further, the west and southwest mesoregions contain 6 of these 13 specialized microregions.

Figure 1. Microregions in Paraná State that specialize in milk production.

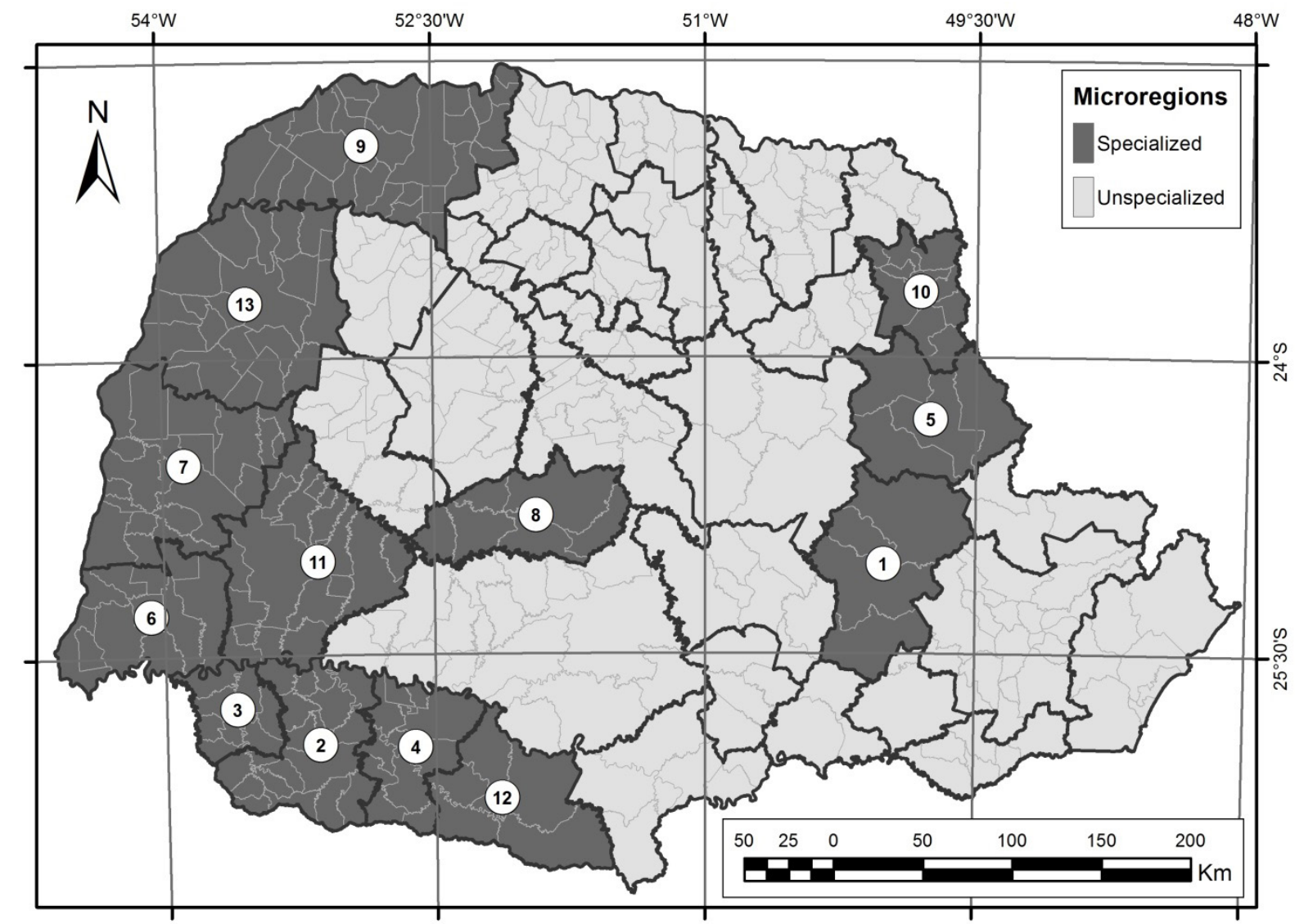

Notes: 1. Ponta Grossa; 2. Francisco Beltrão; 3. Capanema; 4. Pato Branco; 5. Jaguariaíva; 6. Foz do Iguaçu; 7. Toledo; 8. Pitanga; 9. Paranavaí; 10. Wenceslau Braz; 11. Cascavel; 12. Palmas; 13. Umuarama. 
Considering the relative GPV of these specialized microregions between 2000 and 2012, those that comprise the West mesoregion contributed $25.6 \%$, with Toledo alone responsible for $12.8 \%$, Cascavel for $7.3 \%$, and Foz do Iguaçu for 5.5\%. The microregions in the Southwest mesoregion accounted for $20.2 \%$ of milk GPV thanks to Francisco Beltrão (9.3\% of this share), Pato Branco (6.5\%), and Capanema (4.4\%). Another outstanding contributor was Ponta Grossa with $12.4 \%$ of GPV.

Table 2 displays the PCA coefficients determined to have the greatest cumulative variation. According to the selection criteria, these analyses were performed by considering the first two principal components, which helped explain $91.5 \%$ of the variability in the data $(55.6 \%$ for the first component termed "technically enhanced production" and $35.9 \%$ for the second termed "household production"). All components after the third contributed minimally to explaining the variance and therefore were excluded from the analyses. Moreover, the numerical value of each component provided the basis for identifying their predominant characteristics. The first component correlated positively with the GPV, productivity, and $L Q$ variables, while the second component was positively correlated with the PRONAF variable.

Table 2. Coefficients of the linear combinations and principal component analysis (PCA).

\begin{tabular}{lcc}
\hline \multirow{2}{*}{ Variable } & \multicolumn{2}{c}{ Component } \\
\cline { 2 - 3 } & $\mathbf{1}$ & $\mathbf{2}$ \\
\hline PRONAF & -0.130 & 0.993 \\
Gross production value & 0.824 & 0.550 \\
Productivity & 0.898 & -0.192 \\
Location quotient & 0.860 & -0.312 \\
\hline
\end{tabular}

Notes: Component 1. Technologically enhanced production. Component 2. Household production. PRONAF - National Programme for Strengthening Family Farming.

Figure 2 shows the representative dimensions of the technically enhanced and household production components along with the distribution of microregions in Paraná State. The allocation of the microregion and its distance from the center of the component demonstrate the strength of the characteristic (positive or negative). Therefore, the further from the center the microregion in question, the stronger are its respective characteristics. This figure shows the unique features of the Ponta Grossa and Toledo microregions, both of which are far from the center and strongly associated with household production and technically enhanced production, respectively. Moreover, the microregions of Francisco Beltrão, Jaguariaíva, Capanema, Pato Branco, and Foz do Iguaçu stand out for their proximity to the productivity and $L Q$ variables, while the microregions of Cascavel, Umuarama, and Paranavaí are important for the PRONAF variable.

Based on the PCA results, cluster analysis was performed to determine the degree of similarity between microregions. The results enabled the identification of five groups (see Figure 3). Group 1, which consists only of Ponta Grossa, is characterized by a high level of technological improvement, which is translated into both its production and its productivity. According to Parré et al. (2011), the productivity of the herd differs regionally across Paraná State, with cities such as Castro, Palmeira, and Carambeí displaying high productivity. Therefore, although Ponta Grossa presents a lower number of milk production units, it shows higher average productivity. 
Figure 2. Principal component analysis (PCA), by microregion in Paraná State.

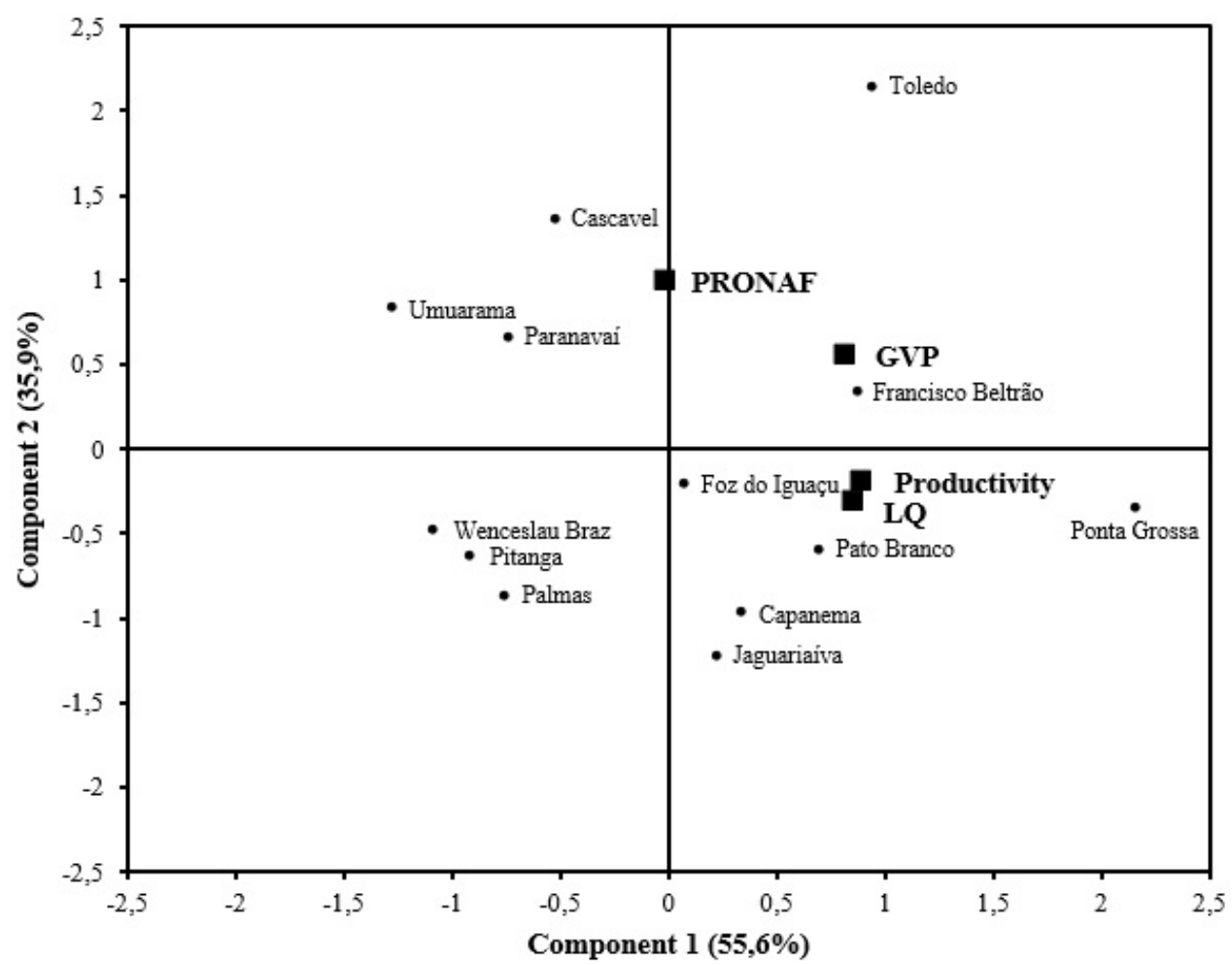

Notes: GVP - gross value production. LQ - location quotient. PRONAF - National Programme for Strengthening Family Farming.

Figure 3. Cluster formation in milk production by microregions in Paraná State.

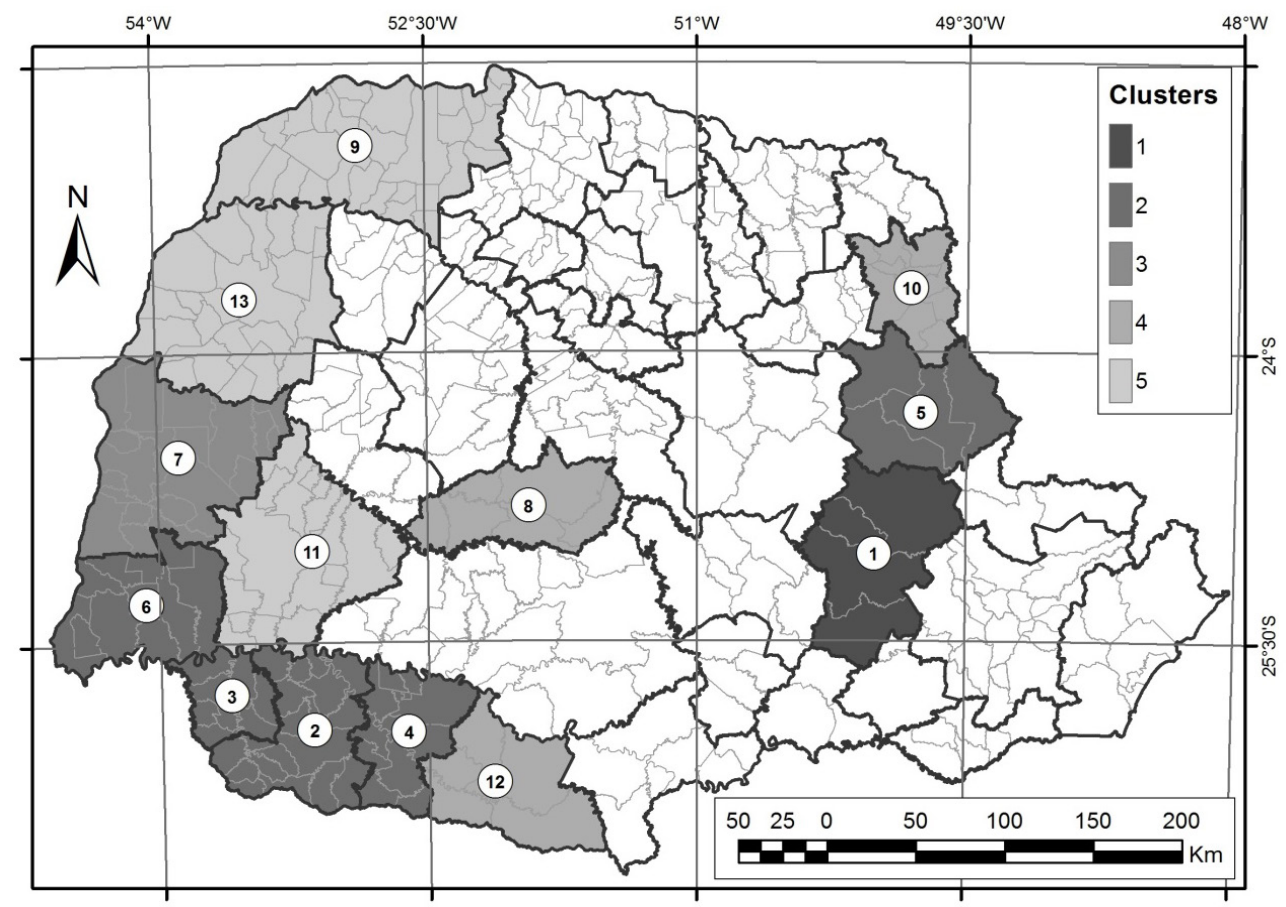

Notes: 1. Ponta Grossa; 2. Francisco Beltrão; 3. Capanema; 4. Pato Branco; 5. Jaguariaíva; 6. Foz do Iguaçu; 7. Toledo; 8. Pitanga; 9. Paranavaí; 10. Wenceslau Braz; 11. Cascavel; 12. Palmas; 13. Umuarama. 
Group 2 consists of the microregions of Francisco Beltrão, Capanema, Pato Branco, Jaguariaíva, and Foz do Iguaçu. The microregion of Jaguariaíva is geographically close to Ponta Grossa, leading to spillover effects in relation to higher production and productivity (CAPUCHO; PARRÉ, 2012). The microregions in Group 2 are located predominantly in the Southwest region, thus their characteristics might be inherent to the Mid-East mesoregion. Although their average productivity rates among the 13 specialized microregions are not the highest, they present high LQ values, especially Francisco Beltrão, Capanema, Pato Branco, Jaguariaíva, and Foz do Iguaçu. Therefore, advances in milk farming in this region can be seen to have resulted from technical improvements in production as well as technical and organizational factors such as the use of herds, a specialized workforce, and an active cooperative structure (PARRÉ et al., 2010). In this region, the search for cooperatives is necessary to overcome the difficulties that farmers encounter when adopting a technically enhanced production model. While technological advances focus on improving productivity, the southwest region of Paraná State is characterized by a predominance of small production units that fight for better conditions by means of various organizational methods such as cooperatives (SCHMITZ; SANTOS, 2013).

Group 3 contains only the Toledo microregion, which stands out because of its high number of milk producers (IBGE, 2007). Toledo households have high levels of investment, since it is the largest recipient of PRONAF funds. This degree of investment is reflected in its high average productivity and high GPV, especially in the cities of Marechal Cândido Rondon and Toledo.

Group 4 is composed of the microregions of Palmas, Pitanga, and Wenceslau Braz. Although these microregions comprise predominantly small households, they are undergoing a transition process to technically enhanced production. They are also affected by the regional spillover effect, as they are all near more specialized microregions (Groups $1-3)$.

Finally, comprising the microregions of Cascavel, Paranavaí, and Umuarama, Group 5 is located in the sandstone region of Caiuá, which makes the milk-producing establishments of this region suffer from poor edaphoclimatic conditions since the soil and climate are unsuitable for milk production activities. The main problem of this group is a lack of farming technology, since they show lower values for the productivity and $L Q$ variables than the other specialized microregions in the state.

Concurring with our findings, Capucho and Parré (2012) formed clusters by using the exploratory spatial analysis method, based on Moran's I statistics, similarly showing a large degree of heterogeneity among milk producers in Paraná State. They identified the west, southwest, and mid-east regions as the most developed milk farming areas, suggesting this as evidence that the modernization of milk farming in the 2000s occurred unequally among the different regions of the state. Carvalho and Hott (2007), in a study of the spatial distribution of milk production in Brazil, also stressed the concentration and hegemony of certain cities in milk production activities in Paraná State, with an emphasis on Castro (microregion of Ponta Grossa) and Marechal Cândido Rondon (microregion of Toledo).

The presented results show that although Paraná is one of the largest milk-producing states in Brazil, regional disparities, even among specialized microregions, are considerable. Even among the 13 specialized microregions examined within, establishments are characterized as having (i) high productivity and a predominance of owner-operated farms; (ii) high productivity and a predominance of household farmers; (iii) less prominent productivity and a predominance of owner-operated farms; and (iv) less prominent productivity and household 
farmers. Moreover, Paraná State shows regional differences in relation to the productivity, $G P V$, and $L Q$ variables, which indicate the need for investment to improve technological standards, even in microregions considered to be specialized in milk farming.

Among the factors favoring synergy in milk production, the optimization of a highly engaged workforce, favorable climate conditions, the predominance of European breeds, nutritional management compatible with the herd, and a cooperative production structure are all important (CAPUCHO; PARRÉ, 2012; LOPES JUNIOR et al., 2012). The edaphoclimatic conditions of each specialized microregion also appear to be an important factor for group formation. Therefore, consideration must be given to the fact that the milk production technologies implemented in each location align with the geo-physical characteristics and agricultural structure of the region.

While farms will always show some regional heterogeneity, inequalities in the productivity, GPV, $L Q$, and PRONAF variables could be minimized if public actions aimed to overcome the bottlenecks in the production systems of each microregion in order to provide production and productivity gains in milk production activities in Paraná State. Therefore, investment must be expanded to areas that already have a certain level of specialization so that the spatial spillover effect occurs naturally and more efficient production systems are widely adopted.

\section{Conclusions}

This study examined the spatial distribution of the microregions specialized in milk production in Paraná State, using livestock data from 2000 to 2012. Based on the results of the LQ analysis, 13 microregions in Paraná State were deemed to specialize in milk production. Then, by means of PCA, two main components, called technically enhanced production and household production, were found to explain $91.5 \%$ of the variability in the data. The first one was created by high-productivity, high GPV, and specialized microregions, while the second comprised microregions with a high utilization of PRONAF investment. Finally, the presented cluster analysis verified the formation of five groups, showing the great heterogeneity in milk production throughout Paraná State, even among the 13 specialized microregions. The dominant factors involved in groups' formation were edaphoclimatic conditions, productivity, technological standards, and agriculture structure (i.e., household production or non-household production). In summary, the spatial distribution of specialized milkproducing microregions in Paraná State is clearly heterogeneous, especially in the mid-east, west, and southwest regions.

\section{Acknowledgments}

We are grateful to João Henrique Caviglione and José Francirlei de Oliveira, for stimulating discussions and comments on the manuscript.

\section{References}

BANCO CENTRAL DO BRASIL - BCB. Sistema Financeiro Nacional. Credito Rural. Anuário Estatístico do Crédito Rural. Disponível em: <http://www.bcb.gov. br>. Acesso em: 20 nov. 2015.

BAZOTTI, A.; NAZARENO, L. R.; SUGAMOSTO, M. Caracterização socioeconômica e técnica da atividade leiteira do Paraná. Revista Paranaense de Desenvolvimento, Curitiba, v. 33, n. 123, p. 213-234, 2012.

BORTOLETO, E. E.; CHABARIBERY, D. Leite e derivados: entraves e potencialidades na virada do século. Informações Econômicas, São Paulo, v. 28, n. 9, p. 25-36, 1998.

CAPUCHO, T.; PARRÉ, J. L. Produção leiteira no Paraná: um estudo considerando os efeitos espaciais. Informe Gepec, Toledo, v. 16, n. 1, p. 112-127, 2012.

CARVAlHO, G. R.; HOTT, M. C. Análise da concentração e geografia da produção de leite no Brasil. Revista de Política Agrícola, Brasília, v. 16, n. 2, p. 8297, 2007. 
CHADDAD, F. Cooperativas no agronegócio do leite: mudanças organizacionais e estratégicas em resposta à globalização. Organizações Rurais \& Agroindustriais, Lavras, v. 9, n. 1, p. 69-78, 2007.

FÁVERO, L. P.; BELFIORE, P. Análise de dados: técnicas multivariadas exploratórias. Rio de Janeiro: Elsevier, 2015. 344 p.

FÁVERO, L. P.; BELFIORE, P.; SILVA, F. L.; CHAN, B. L. Análise de dados: modelagem multivariada para tomada de decisões. Rio de Janeiro: Elsevier, 2009. 646 p.

FERNANDES, E. N.; BRESSAN, M.; VERNEQUE, R. S. Zoneamento da pecuária leiteira da região sul do Brasil. Ciência Rural, Santa Maria, v. 34, n. 2, p. 485491, 2004.

INSTITUTO BRASILEIRO DE GEOGRAFIA E ESTATÍSTICA - IBGE. Censo Agropecuário 2006. Rio de Janeiro: IBGE, 2007.

Pesquisa pecuária municipal. Disponível em: $\overline{<\mathrm{http}: / / w w w . i b g e . g o v . b r />}$. Acesso em: 15 set. 2015.

ISARD, W. Methods of regional analysis. Cambridge: The MIT Press, 1960. 784 p.

LANGE, M. J.; ZAMBOM, M. A.; RAMOS, C. E. C. O.; CASTAGNARA, D. D.; BÁNKUTI, F. I.; NEUMANN, M. E.; BRITO, M. M.; TININI, R. C. R. Tipologia de sistemas de produção leiteiros baseados nas características produtivas e de manejo na região oeste do Paraná. Semina: Ciências Agrárias, Londrina, v. 37, n. 1, p. 473-482, 2016.

LEMOS, M. B.; GALINARI, R.; CAMPOS, B.; BIASI, E.; SANTOS, F. Tecnologia, especialização regional e produtividade: um estudo da pecuária leiteira em Minas Gerais. Revista de Economia e Sociologia Rural, Brasília, v. 41, n. 3, p. 117-138, 2003.

LOPES JUNIOR, J. F.; RAMOS, C. E. C. O.; SANTOS, G. T.; GRANDE, P. A.; DAMASCENO, J. C.; MASSUDA, E. M. Análise das práticas de produtores em sistemas de produção leiteiros e seus resultados na produção e qualidade do leite. Semina: Ciências Agrárias, Londrina, v. 33, n. 3, p. 1199-1208, 2012.

MARION FILHO, P. J.; FAGUNDES, J. O.; SCHUMACHER, G. A produtividade, a especialização e a concentração da produção de leite nas microrregiões do Rio Grande do Sul (1990-2009). Revista em Agronegócio e Meio Ambiente, Maringá, v. 5, n. 1, p. 82-101, 2012.

MARION FILHO, P. J.; MOURA, A. C.; BRITES, M.; LORENZONI, R. K. Concentração regional e especialização na produção de leite do Rio Grande do Sul (1990 - 2010). Revista Brasileira de Gestão e Desenvolvimento Regional, Taubaté, v. 11, n. 1, p. 224242, 2015.

MARION FILHO, P. J.; OLIVEIRA, L. F. V. A especialização e a concentração da produção de leite nas microrregiões do Rio Grande do Sul (1990-2007). Ensaios FEE, Porto Alegre, v. 31, p. 635-647, 2011. Número Especial.

MARTINS, M. C. Competitividade da cadeia produtiva do leite no Brasil. Revista de Política Agrícola, Brasília, v. 12, n. 3, p. 38-51, 2004.

MONTEIRO, A. A.; TAMANINI, R.; SILVA, L. C. C.; MATTOS, M. R.; MAGNANI, D. F.; D’OLVIDIO, L.; NERO, L. A.; BARROS, M. A. F.; PIRES, E. M. F.; PAQUEREAU, B. P. D.; BELOTI, V. Características da produção leiteira da região do agreste do estado de Pernambuco, Brasil. Semina: Ciências Agrárias, Londrina, v. 28, n. 4, p. 665-674, 2007.

PARRÉ, J. L.; BÁNKUTI, S. M. S.; ZANMARIA, N. A. Perfil socioeconômico de produtores de leite da região sudoeste do Paraná: um estudo a partir de diferentes níveis de produtividade. Revista de Economia e Agronegócio, Viçosa, MG, v. 9, n. 2, p. 275-300, 2011.

PARRÉ, J. L.; SANTOS, G. T.; MASSUDA, E. M.; ALVES, A. F. Análise espacial da produção e produtividade da pecuária leiteira paranaense. In: SANTOS, G. T.; MASSUDA, E M.; KAZAMA, D. C. S.; JOBIM, C. C.; BRANCO, A. F. (Org.). Bovinocultura leiteira: bases zootécnicas, fisiológicas e de produção. Maringá: Eduem, 2010. p. 29-46.

SANTOS, P. L. S.; AZEVEDO, E. O. Perfil socioeconômico de produtores de leite do estado da Paraíba, Brasil. Revista Caatinga, Mossoró, v. 22, n. 4, p. 260-267, 2009.

SCHMITZ, A. M.; SANTOS, R. A. A produção de leite na agricultura familiar do Sudoeste do Paraná e a participação das mulheres no processo produtivo. Terra Plural, Ponta Grossa, v. 7, n. 2, p. 339-355, 2013.

TELlES, T. S.; TANAKA, J. M. U.; PELlinI, T. Agricultura familiar: pecuária leiteira como locus das políticas públicas paranaenses. Semina: Ciências Agrárias, Londrina, v. 29, n. 3, p. 579-590, 2008.

ZOCCAL, R.; GOMES, A. T. Zoneamento da produção de leite. In: ZOCCAL, R.; CARVALHO, L. A.; MARTINS, P. C.; ARCURI, P. B.; MOREIRA, M. S. P. (Org.). A inserção do Brasil no mercado internacional de lácteos. Juiz de Fora: Embrapa Gado de Leite, 2005. p. $163-180$. 
